\title{
Experimental Study of Photovoltaic Thermal-thermoelectric (PVT-TE) Air Collector
}

\author{
Nurul Syakirah Nazri, Ahmad Fudholi, Mohd Hafidz Ruslan, Kamaruzzaman Sopian \\ Solar Energy Research Institute, Universiti Kebangsaan Malaysia, Malaysia
}

\begin{tabular}{|c|c|}
\hline Article Info & ABSTRACT \\
\hline Article history: & \multirow{10}{*}{$\begin{array}{l}\text { In this study, an experimental study has been conducted to determine the } \\
\text { performance of the photovoltaic thermal- thermoelectric air collector (PVT- } \\
\text { TE) hybrid system. Hybrid system consists of photovoltaic panel (PV) and } \\
\text { thermoelectric modules (TEs) that can improve the energy efficiency of the } \\
\text { system. The results of output temperature }\left(\mathrm{T}_{\mathrm{o}}\right) \text { and plate temperature }\left(\mathrm{T}_{\mathrm{p}}\right) \\
\text { obtained from the experiment have been used to determine the performance } \\
\text { of this hybrid system. Effect of mass flow rate and radiation intensity is also } \\
\text { being investigated. Experimental studies were carried out at } 0.02 \mathrm{~kg} / \mathrm{s} \text { and } \\
0.09 \mathrm{~kg} / \mathrm{s} \text { which represent minimum and maximum of mass flow rate, and } \\
\text { radiation intensities in the range of } 268-922 \mathrm{~W} / \mathrm{m}^{2} \text {. } \\
\text { Copyright } \odot 2018 \text { Institute of Advanced Engineering and Science. } \\
\text { All rights reserved. }\end{array}$} \\
\hline Received Jan 29, 2018 & \\
\hline Revised Jul 26, 2018 & \\
\hline Accepted Aug 6, 2018 & \\
\hline Keyword: & \\
\hline \multirow{5}{*}{$\begin{array}{l}\text { Energy analysis } \\
\text { Heat transfer } \\
\text { PVT } \\
\text { Solar energy }\end{array}$} & \\
\hline & \\
\hline & \\
\hline & \\
\hline & \\
\hline \multicolumn{2}{|l|}{ Corresponding Author: } \\
\hline \multicolumn{2}{|c|}{$\begin{array}{l}\text { Nurul Syakirah Nazri, } \\
\text { Solar Energy Research Institute, Universiti Kebangsaan Malaysia, } \\
43600 \text { Bangi Selangor, Malaysia. } \\
\text { Email: syakirahnurul@yahoo.com; a.fudholi@ukm.edu.my }\end{array}$} \\
\hline
\end{tabular}

\section{INTRODUCTION}

The evolution of renewable energy sources such as solar energy is a source of energy that provides benefits to the environment and clean energy. In fact, this energy is also an alternative source to the poor or rural people who can not use modern energy sources. Thermal and electrical energy can be generated from solar energy. These two energies are produced in different forms but they can be produced simultaneously if hybrid collectors are used. This hybrid system is made up of a combination of two types of collectors, namely thermal collector and photovoltaic (PV) in a unit called the photovoltaic-thermal (PVT) collector. PVT collector is a device designed to receive solar energy, convert it into thermal and electrical energy, which transfer the thermal energy to the fluid that flows into the collector. A PVT collector consists of PV panel, insulation and frame. Accordingly, PVT collector consists of one or more cover (glass sheets) or a transparent material placed above an absorbing plate with air flowing around it [1-7].

Heat energy can also be divided into two mediums namely water and air. Both fluids absorb heat and are used as heat transfer mediums in PVT collectors. This is because the high temperatures in the environment and solar radiation can affect the power output of the PV system. If the temperature on the panel increases, the efficiency of the solar panel output power will decrease [8-11]. By then, cooling of the PV panel is needed to increase the efficiency of the panel. At optimum levels, electrical efficiency can be controlled simultaneously with dropping temperature of panel. Therefore, PVT collectors can generate sustainable energy as overall efficiencies increases.

Passive and active cooling systems have their own limitations. The active cooling system not only requires electricity to operate but also wastes the heat transferred to the environment. To overcome this disadvantages, thermoelectric devices (TEs) that function as fins can absorb wasted heat by attach the device at the back of PV panel. The performance of the TE module can be identify by the temperature at the cold and hot side of the device and also figure of merit. PV panel cooling system has reviewed by [12] using TE 
with heat absorption by the device. TE has benefits such as compress in size, lightweight and energy-efficient compression. Additionally, direct current sources (DC) such as fuel cells and PV cells can be used as a power source for TE [13]. When a low power current is applied to the TE device, heat can be transferred through the module from one side to the other. Then, one side of the module will cool down and the other one will heat up. At cold side temperatures, this cooling system occurs using electrons instead of refrigerants as heat carriers and is suitable for outdoor use in combination with solar cells [14]. Accordingly, the TE module can be used for heating and cooling and is ideal for temperature control applications. Furthermore, the TE device can be used as a heat pump for heating during winter.

In most cases, PVT collectors typically consist of absorbing plates, PV cells, and heat removal systems and typically PV cells attached to the absorbing plate [15-19]. TE design in this study is the most common for PV-TE system consisting of TE module and is equipped with several components. Among of these, the back PV cell with an aluminum sheet located between them to flow the heat lost on the back surface of the PV cell. A model was developed by [20] and optimization method was introduced for solar terrestrial of TE (STEG). In addition, energy-saving modules using the TE combined with solar system can be achieved by studying the cooling efficiency of the modules [21]. The performance of the module combination depends on several parameters such as flow rate of cooling water, solar cell temperature, and TE heat module temperature. This combined module is used in chamber and the result shows that the temperature differences can be achieved by $16.2 \%$ between the ambient air and temperature in chamber. The solar-powered mobile system design combined with TE was studied by [22] using the first and second law of thermodynamics. All the components in the solar still are studied to identify the total heat loss of each component.

For this study, the authors have conducted an experiment to determine the effect of TE devices on energy efficiency for the whole hybrid system. According to the authors' knowledge, it can be concluded that the study of thermal equilibrium on the PVT system is limited and studies on PVT-TE hybrids have not been studied by any previous researchers.

\section{MATERIAL AND METHOD}

The thermal photovoltaic hybrid system consists of air collectors and TE modules. The system has been installed and designed at the Solar Energy Research Institute, UKM (Malaysia). The type of PV panel is mono-crystalline silicon solar cells with a total area of $0.52 \mathrm{~m}^{2}$ each. The residual heat absorbed by air collectors can be used to develop a PV-TE hybrid module by affixing the TE device behind the PV module as shown in Figure 1.

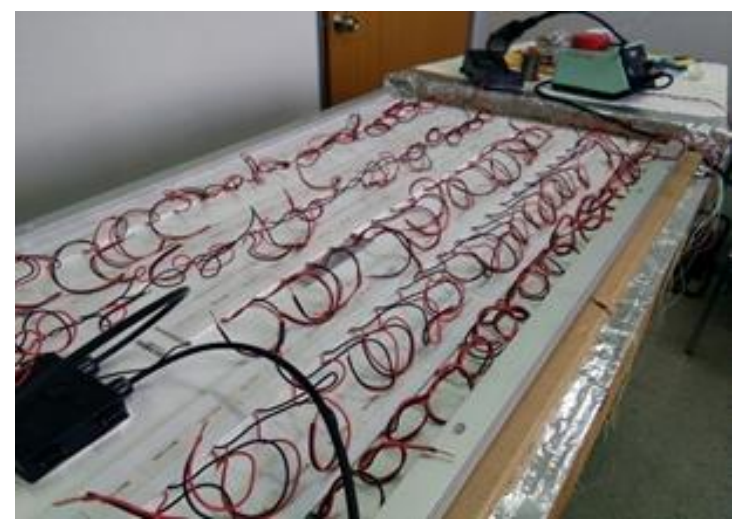

Figure 1. The TE device is attached behind the PV module

The addition of electricity produced by the TE converter can be achieved as there is a temperature difference between the cool and hot side of the TE module. The selected elements of TE module are model (TEC1-12706) which are connected in series with the 110-modules specified in Table 1. By increasing the number of TE modules, the quantity of power consumption will also increase. Therefore, high electrical energy will be generated and each parameter will affect it in a different way. Furthermore, thermal performance can be increased by using silicon thermal paste when attach the TE module behind the PV panel. The study was conducted in Bandar Baru Bangi from $3^{\text {rd }}$ to $25^{\text {th }}$ August. The experiments were carried out using two airflow rates of $0.02 \mathrm{~kg} / \mathrm{s}$ and $0.09 \mathrm{~kg} / \mathrm{s}$ which represents the minimum and maximum value. 
To get the results, appropriate equipment should be used to obtain the desired parameters for assessing system performance. The measurement of the amount of solar radiation is measured using a pyranometer. Data logger with K-type thermocouples are also used to measure different temperatures including temperatures on the top and bottom of the PV as well as the hot and cool side of the TE module. Then, multimeter type A Fluke 15B + is used to measure current output and PV voltage, as well as electric current of TE modules.

Table 1. Module Specification of TE and PV

\begin{tabular}{|c|c|c|c|}
\hline \multicolumn{2}{|l|}{ TE module } & \multicolumn{2}{|l|}{ PV module } \\
\hline Characteristics & Value & Characteristics & Value \\
\hline Type of TE & TEC1-12706 & Cell type & Mono-Si \\
\hline Electric current I (A) & 6 & Short circuit current $I_{\mathrm{sc}}(\mathrm{A})$ & 4.8 \\
\hline Voltage U (V) & 15.2 & Open circuit voltage $\mathrm{V}_{\mathrm{oc}}(\mathrm{V})$ & 22.2 \\
\hline Internal resistance $\mathrm{R}(\Omega)$ & 2.05 & Maximum power $\mathrm{P}_{\max }(\mathrm{W})$ & 80 \\
\hline Couple $\mathrm{N}$ & 127 & PV dimension (mm) & $963 \times 540 \times 30$ \\
\hline Module dimension (mm) & $40 \times 40 \times 4.2$ & Voltage at $\mathrm{PmpV}_{\mathrm{mp}}(\mathrm{V})$ & 18.2 \\
\hline $\begin{array}{l}\text { Max temperature between hot and cold } \\
\text { side } \Delta \mathrm{T}(\mathrm{K})\end{array}$ & 68 & Current at Pmp $\mathrm{I}_{\mathrm{mp}}$ (A) & 4.45 \\
\hline Maximum cooling capacity Q (W) & 56.5 & Cell efficiency $(\%)$ & 15 \\
\hline
\end{tabular}

Solar radiation is considered to be the main source of energy in collector with the surface of the PV panel. The affected part of solar radiation will be absorbed by the PVT layer and the rest is transferred to the working fluid. Thermal efficiency $\left(\eta_{t h}\right)$ depends largely on the obtained heat $\left(Q_{u}\right)$ and the temperature output $\left(T_{o}\right)$ below the specified airflow rate in the collector channel. This thermal efficiency $\left(\eta_{t h}\right)$ is generally regarded as instantaneous efficiency in the PVT system due to instantaneous operating conditions such as solar radiation, surrounding temperature, wind speed and so on. The basic parameters can be defined as the ratio of useful energy that transfered to the energy of the collector system. This relationship can be shown as [23-27]:

$$
\eta_{t h}=\frac{Q_{u}}{A S}
$$

and

$$
Q_{u}=\dot{m} C\left(T_{o}-T_{i}\right)
$$

The use of fins attached to the back of the collector shows it is more practical in design and gives superior results as a heat absorber medium. The overall efficiencies depend on the amount of fin per unit length (fin density) as well as the effectiveness of individual fin. According to [14], the proposed electricity conversion efficiency of the proposed PV-TE system is in the range of 1-4\%. Therefore, the author can state that it is an exciting new alternative to power generation especially in remote areas where it can improve indoor ventilation for hot and humid areas. For thermoelectric generators operated by solar energy, the following equations are as follows:

$$
\eta_{T E}=\frac{1}{4} \frac{\alpha^{2}}{K R}(\Delta T)
$$

Here $\eta_{\mathrm{TE}}$ is the efficiency of the thermoelectric system, $\Delta \mathrm{T}$ is the temperature difference on both sides of the thermoelectric and $\alpha, \mathrm{R}$ and $\mathrm{K}$ are Seebeck coefficients, electrical resistance and thermal conductivity of the modules. With this, to achieve high efficiency of $\eta_{\mathrm{TE}}, \Delta \mathrm{T}$ should achieve the highest possible temperature and high Seebeck coefficients are also required. However, low electrical and low thermal conductivity need to be achieved. Some assessments have been studied to calculate the electrical efficiency of PV and there are many studies that indicate that temperature of PV mainly affects the energy performance. To determine the efficiency of the photovoltaic panel, it can be expressed as the following equation:

$$
\eta_{p v}=\eta_{0}\left[1-0.0045\left(T_{p v}-25\right)\right]
$$


The performance of the PVT system can be described by a combination of efficiency [28]. It consists of thermal efficiency $\left(\eta_{\mathrm{th}}\right)$ and electrical efficiency $\left(\eta_{\mathrm{el}}\right)$. This efficiency usually includes a useful thermal acquisition ratio and electricity acquisition from the system to solar radiation towards collector gap within a certain time or period. In this study, the TE module can also produce electrical energy so that the total efficiency known as overall efficiency $\left(\eta_{\mathrm{T}}\right)$ can be used to evaluate the overall performance of the system which can be determined by the following equation:

$$
\eta_{T}=\eta_{t h}+\eta_{T E G}+\eta_{p v}
$$

\section{RESULT AND DISCUSSION}

The average solar radiation of the PVT-TE hybrid system on weekdays is recorded from 11.00 to 15.30 to obtain different solar radiation. Based on observation, the maximum air temperature of the outlet temperature is $40 \mathrm{oC}$ at mass flow rate of $0.02 \mathrm{~kg} / \mathrm{s}$ with highest radiation intensity as shown in Figure 2.

From Figure 2, the maximum of $\mathrm{T}_{\mathrm{o}}$ and $\mathrm{T}_{\mathrm{p}}$ obtained is $40{ }^{\circ} \mathrm{C}$ and $75{ }^{\circ} \mathrm{C}$ respectively with solar radiation of $900 \mathrm{~W} / \mathrm{m}^{2}$. The pattern of the graph is non uniform due to the fluctuation of solar radiation. The average reduction in the temperature of the solar cell is also due to the thermal transfer from the back of the solar cell to the air through the TE module. Therefore, the yield of electricity is higher in low PV cell temperature due to low electron collisions in the area of solar cell depletion.

In Figure 3, the maximum value of $\mathrm{T}_{\mathrm{o}}$ and $\mathrm{T}_{\mathrm{p}}$ is increase with increasing of solar radiation. Thus, the maximum value of $\mathrm{T}_{\mathrm{o}}$ is $39^{\circ} \mathrm{C}$ and $62^{\circ} \mathrm{C}$ for $\mathrm{T}_{\mathrm{p}}$ with $860 \mathrm{~W} / \mathrm{m}^{2}$ of solar radiation. After $2.00 \mathrm{p} . \mathrm{m}$, it can be seen that the temperature of $\mathrm{T}_{\mathrm{p}}$ decrease with decreasing of solar radiation. It can be said that solar cell temperature decreases with increased mass flow rate thus increasing the efficiency of the cell.

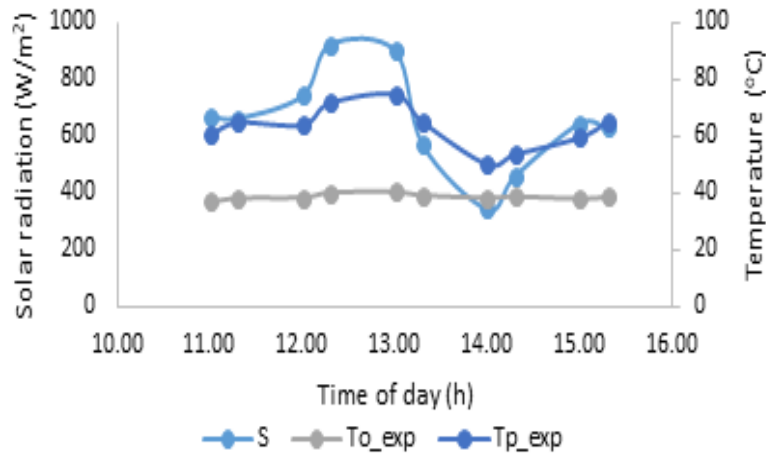

Figure 2. Temperature of $\mathrm{T}_{\mathrm{o}}$ and $\mathrm{T}_{\mathrm{p}}$ at mass flow rate $\mathrm{m}=0.02 \mathrm{~kg} / \mathrm{s}$

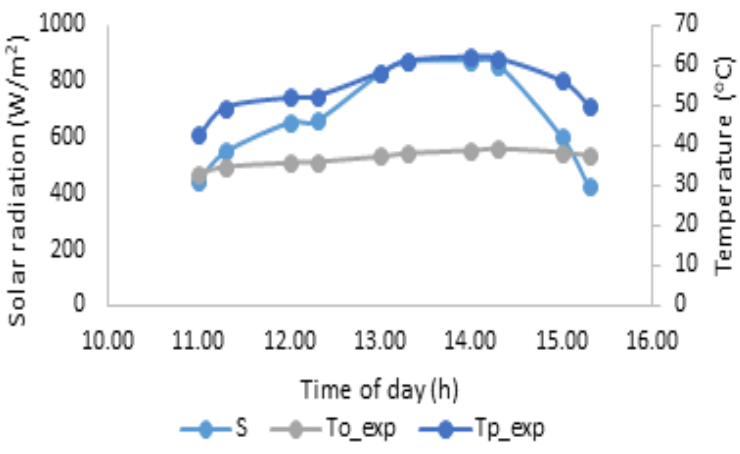

Figure 3. Temperature of $\mathrm{T}_{\mathrm{o}}$ and $\mathrm{T}_{\mathrm{p}}$ at mass flow rate $\mathrm{m}=0.09 \mathrm{~kg} / \mathrm{s}$

The influence of mass flow rate affects the efficiency of the system as the mass flow rate through the channel in the collector cause a cooling effect to the photovoltaic cells. Based on Table 2 and 3 , it can be seen that the efficiency analysis at different mass flow rates gives rise to thermal efficiency where the increase of 0.310 to 0.597 at mass flow rate $0.02 \mathrm{~kg} / \mathrm{s}$ and $0.09 \mathrm{~kg} / \mathrm{s}$. This thermal efficiency change is in line with the increase of mass flow rate.

Normally, PV cell efficiency will decrease when PV cell temperature increases. The performance of the TE module can be improved when the heat accumulated on the surface of the PV cell is absorbed by the TE and increases the temperature difference between the sides of TE module. Hence, the efficiency of the hybrid system can be improved as the TE module efficiency increase is greater than the reduction of PV cell efficiency. Based on the above results, the TE module's electrical efficiency is higher at lower mass flow rates as the time required for heat transfer from TE module to air is longer.

Based on the above results, the TE module's electrical efficiency is higher at lower mass flow rates as the time required for heat transfer from TE module to ambient is longer. However, the average electrical efficiency of TE module in this study is low from 0.006-0.023 because the performance of selected TE module in this study is lower than that of the more commercial TE modules. 
Table 2. Variation Efficiencies at Mass Flow Rate $\mathrm{m}=0.02 \mathrm{~kg} / \mathrm{s}$

\begin{tabular}{ccccc}
\hline $\begin{array}{c}\text { Intensit } \\
\mathrm{y}\end{array}$ & $\eta p \mathrm{v}$ & $\eta \mathrm{TE}$ & $\eta \mathrm{t}$ & $\eta \mathrm{T}$ \\
\hline 342 & 0.115 & 0.009 & 0.310 & 0.434 \\
461 & 0.112 & 0.012 & 0.309 & 0.433 \\
567 & 0.109 & 0.015 & 0.308 & 0.432 \\
628 & 0.108 & 0.016 & 0.307 & 0.431 \\
645 & 0.108 & 0.017 & 0.307 & 0.431 \\
662 & 0.107 & 0.017 & 0.307 & 0.431 \\
670 & 0.107 & 0.017 & 0.307 & 0.431 \\
741 & 0.105 & 0.019 & 0.306 & 0.430 \\
900 & 0.101 & 0.023 & 0.304 & 0.428 \\
922 & 0.101 & 0.023 & 0.304 & 0.428 \\
\hline
\end{tabular}

Table 3. Variation efficiencies at mass flow rate $\mathrm{m}=0.09 \mathrm{~kg} / \mathrm{s}$

\begin{tabular}{ccccc}
\hline $\begin{array}{c}\text { Intensit } \\
\mathrm{y}\end{array}$ & $\eta \mathrm{pv}$ & $\eta \mathrm{TE}$ & $\eta \mathrm{t}$ & $\eta \mathrm{T}$ \\
\hline 268 & 0.119 & 0.006 & 0.597 & 0.721 \\
384 & 0.117 & 0.008 & 0.596 & 0.720 \\
424 & 0.116 & 0.009 & 0.595 & 0.720 \\
447 & 0.115 & 0.009 & 0.595 & 0.720 \\
550 & 0.113 & 0.011 & 0.595 & 0.719 \\
600 & 0.113 & 0.012 & 0.594 & 0.719 \\
653 & 0.112 & 0.013 & 0.594 & 0.718 \\
660 & 0.111 & 0.013 & 0.594 & 0.718 \\
830 & 0.108 & 0.017 & 0.592 & 0.717 \\
859 & 0.108 & 0.017 & 0.592 & 0.717 \\
\hline
\end{tabular}

The overall efficiency of collectors is also examined by the amount of thermal efficiency and electrical efficiency of the collector. Based on the above results, the correlation between mass flow rates is proportional to the increase in the overall efficiency of the collector.

\section{CONCLUSION}

The effects of various mass flow rates on energy analysis have been presented. Therefore, it can be concluded that temperature is the main factor among these parameters that affects the efficiency of the hybrid system conversion. In addition, the parameters studied are also important to select the appropriate values for the convection heat transfer coefficient and the focus ratio to maintain a greater temperature differences between the two sides of TE module.

\begin{tabular}{|c|c|c|c|}
\hline \multicolumn{4}{|c|}{ NOMENCLATURE } \\
\hline $\bar{A}$ & area $\left(\mathrm{m}^{2}\right)$ & & Greek symbols \\
\hline$C$ & specific heat of air $\left(\mathrm{J} / \mathrm{kg}{ }^{\circ} \mathrm{C}\right)$ & & Seebeck coefficients \\
\hline I & electric current (A) & $\alpha$ & efficiency \\
\hline$k$ & thermal conductivity $\left(\mathrm{W} / \mathrm{m}^{\circ} \mathrm{C}\right)$ & $\eta$ & \\
\hline K & module thermal conductance $\left(\mathrm{W} /{ }^{\circ} \mathrm{C}\right)$ & & \\
\hline$\dot{m}$ & mass flow rate $(\mathrm{kg} / \mathrm{s})$ & & Subscripts \\
\hline$P$ & electrical power generation of TE (W) & & electrical \\
\hline$P V$ & photovoltaic & el & inlet \\
\hline$P V T$ & photovoltaic thermal & $i$ & outlet \\
\hline$Q_{u}$ & useful thermal energy (W) & $o$ & photovoltaic \\
\hline$Q_{n}$ & heat transfer rate of TE (W) & $p$ & total \\
\hline$R$ & electrical resistance of TE $(\Omega)$ & $T$ & thermoelectric \\
\hline$S$ & solar radiation $\left(\mathrm{W} / \mathrm{m}^{2}\right)$ & $T E$ & thermoelectric generator \\
\hline$T$ & temperature $\left({ }^{\circ} \mathrm{C}\right)$ & $T E G$ & thermal \\
\hline$T E$ & thermoelectric & th & initial value \\
\hline & & 0 & \\
\hline
\end{tabular}

\section{ACKNOWLEDGEMENTS}

The authors would like to thank the UKM for funding (GP-K020448) and (GGP-2017-045).

\section{REFERENCES}

[1] N.S. Nazri, A. Fudholi, B. Bakhtyar, C.H. Yen, A. Ibrahim, M.H. Ruslan, S. Mat, K. Sopian, "Energy economic analysis of photo-voltaic-thermal-thermoelectric (PVT-TE) air collectors". Renewable and Sustainable Energy Review, vol. 92, pp. 187-97, 2018.

[2] C.N. Aisyah, A. Fudholi, M.Y. Othman, A. Ibrahim, M.H. Ruslan, K. Sopian, "Kecekapan pengumpul PV/T menggunakan pengumpul terma reka bentuk pilin (Efficiency of PV/T collector using spiral thermal absorber design), Sains Malaysiana, vol. 47, no. 4, pp. 853-859, 2018

[3] A. Lekbir, C.K. Gan, M.R. Ab Ghani, T. Sutikno., "The recovery of energy from a hybrid system to improve the performance of a photovoltaic cell“", International Journal of Power Electronics and Drive Systems (IJPEDS), vol. 9, no. 3, pp. 957-964, 2018.

[4] N.S. Nazri, A. Fudholi, M.H. Ruslan, K. Sopian, "Mathematical modeling of photovoltaic thermal-thermoelectric (PVT-TE) air collector“. International Journal of Power Electronics and Drive Systems (IJPEDS), vol. 9, no. 2, pp. 795-802, 2018. 
[5] M. Zohri, N. Nurato, L.D. Bakti, A. Fudholi., "Exergy assessment of photovoltaic thermal with v-groove collector using theoretical study“. TELKOMNIKA, vol. 16(2), pp. 550-57, 2018.

[6] M. Zohri, Nurato, A. Fudholi, "Photovoltaic thermal (PVT) system with and without fins collector: theoretical approach“. International Journal of Power Electronics and Drive System (IJPEDS), vol. 8, no. 4, pp. 1756-63, 2017.

[7] A. Fudholi, K. Sopian., "Review on exergy and energy analysis of solar air heater". International Journal of Power Electronics and Drive Systems (IJPEDS), vol. 9, no. 1, pp. 420-26, 2018.

[8] A. Fudholi, K. Sopian., "Review on solar collector for agricultural produce“. International Journal of Power Electronics and Drive Systems (IJPEDS), vol. 9, no. 1, pp. 414-19, 2018.

[9] A. Fudholi, L.C. Haw, K. Sopian, A.M.O. Abdumula, "Primary study of tracking photovoltaic system for mobile station in Malaysia“. International Journal of Power Electronics and Drive Systems (IJPEDS), vol. 9(1), pp. 42732, 2018.

10] A. Fudholi, K. Sopian., "R\&D of photovoltaic thermal (PVT) systems: an overview". International Journal of Power Electronics and Drive Systems (IJPEDS), vol. 9(2), pp. 803-10, 2018

[11] M. Benghanem, A.A. Al-Mashraqi, K.O. Daffallah. „Performance of solar cells using thermoelectric module in hot sites. Renewable Energy 89: 51-59, 2016.

[12] R. Lamba, S.C. Kaushik, "Modeling and performance analysis of a concentrated photovoltaic- thermoelectric hybrid power generation system. Energy Conversion and Management 115: 288-298, 2016.

[13] D. Zhao, G. Tan, G. "A review of thermoelectric cooling: Materials, modeling and applications". Applied Thermal Engineering, vol 66, pp 15-24, 2014.

[14] H. Xi, L. Luo, G. Fraisse, "Development and applications of solar-based thermoelectric technologies,"Renewable and Sustainable Energy Reviews, vol. 11, pp 923-936, 2007.

[15] T.T. Chow, "A review on photovoltaic/thermal hybrid solar technology", Applied Energy, vol. 87, pp 365-379, 2009.

[16] R. Kumar, M.A. Rosen, "A critical review of photovoltaic thermal solar collectors for air heating", Applied Energy, vol. 88, pp 3603-3614, 2011.

[17] M.A. Hasan, K. Sumathy, "Photovoltaic thermal module concepts and their performance analysis: a review", Renewable and Sustainable Energy Reviews, vol. 14, pp. 1845-1859, 2010.

[18] X. Zhang, X. Zhao, S. Smith, J. Xu, X. Yu, "Review of R\&D progress and practical application of the solar photovoltaic/thermal (PV/T) technologies", Renewable and Sustainable Energy Reviews, vol. 16, pp. 599-617, 2012.

[19] M.Y. Othman, A. Ibrahim, G.L. Jin, M.H. Ruslan, K. Sopian, K. "Photovoltaic-thermal (PV/T) technology-the future energy technology", Renewable Energy, vol. 49, pp. 171-174, 2013.

[20] D. Kraemer, K. McEnaney, M. Chiesa, G. Chen, "Modeling and optimization of solar thermoelectric generators for terrestrial applications", Solar Energy, vol. 86, pp. 1338-1350, 2012.

[21] T.C. Cheng, C.H. Cheng, Z. Huang, G-C. Liao, "Development of an energy-saving module via combination of solar cells and thermoelectric coolers for green building applications", Energy, vol. 36, pp. 133-140, 2011.

[22] A.A. Dehghan, A. Afshari, N. Rahbar, "Thermal modeling and exergetic analysis of a thermoelectric assisted solar still", Solar Energy, vol. 115, pp. 277-288, 2015.

[23] J.C. Mojumder, H.C. Ong, W.T. Chong, S. Shamshirband, A.Al-Mamoon, "Application of support vector machine for prediction of electrical and thermal performance in PV/T system", Energy and Buildings, vol. 111, pp. 267-277, 2016.

[24] A Fudholi, K Sopian, M.A. Alghoul, MH Ruslan, MY Othman, "Performances and improvement potential of solar drying system for palm oil fronds". Renewable Energy, vol. 78, pp. 561-565, 2015.

[25] A. Fudholi, K. Sopian, M.Y. Othman, M.H. Ruslan, B. Bakhtyar, "Energy analysis and improvement potential of finned double-pass solar collector," Energy Conversion and Management, vol. 75, pp. 234-40, 2013.

[26] A. Fudholi, K. Sopian, M.H. Ruslan, M.Y. Othman, "Performance and cost benefits analysis of double-pass solar collector with and without fins," Energy Conversion and Management, vol. 76, pp. 8-19, 2013.

[27] A. Fudholi, M. Zohri, G.L. Jin, A. Ibrahim, C.H. Yen, M.Y. Othman, M.H. Ruslan, K. Sopian., "Energy and exergy analyses of photovoltaic thermal collector with $\nabla$-groove," Solar Energy, vol. 159, pp. 742-50, 2018.

[28] W. He, Y. Zhang, J. Ji, "Comparative experiment study on photovoltaic and thermal solar system under natural circulation of water". Applied Thermal Engineering, vol. 31, pp. 3369-76, 2011.

\section{BIOGRAPHIES OF AUTHORS}



Nurul Syakirah Nazri obtained M.Sc (2014) in applied physics and curenly is candidate Ph.D in University Kebangsaan Malaysia (UKM), Malaysia. Her M.Sc thesis was on Heat Exchanger Efficiency Analysis of Assisted Solar Dryer System for Drying Catfish under supervisor by Prof. Dr. Mohd Hafidz Ruslan (main supervisor) and Dr. Ahmad Fudholi (co. supervisor). Her Ph.D project is about photovoltaic thermal-thermoelectric (PVT-TE) hybrid system under supervisor by Dr. Ahmad Fudholi (main supervisor), Prof Dato' Dr. Kamaruzzaman and Prof Dr Mohd Hafidz Ruslan (co. supervisor). More than 5 papers currently under review in journals indexed by Scopus and high impact journals. 


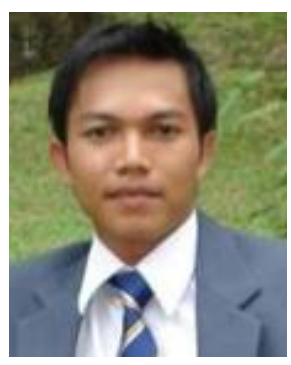

Ahmad Fudholi, Ph.D, M.Sc obtained his S.Si (2002) in physics. He was born in 1980 in Pekanbaru, Indonesia. He served as was the Head of the Physics Department at Rab University Pekanbaru, Riau, Indonesia, for four years (2004-2008). A. Fudholi started his master course in Energy Technology (2005-2007) at Universiti Kebangsaan Malaysia (UKM). His M.Sc thesis was on Wind/PV Hybrid System, and his Ph.D thesis was about the Finned Double-Pass Solar Collectors for Drying of Seaweed. His M.Sc and Ph.D theses were conducted under the supervision of Prof. Dato' Dr. Kamaruzzaman Sopian. After obtaining his Master's, he became a research assistant at UKM until. After his Ph.D (2012) in renewable energy, he became postdoctoral in the Solar Energy Research Institute (SERI) UKM until 2013. He joined the SERI as a lecturer in 2014. He received more than USD 350,000 worth of research grant (16 grant/project) in 2014-2018. He supervised and completed more than 27 M.Sc projects. To date, he has managed to supervise five Ph.D (four as main supervisors and one as co-supervisor), three Master's student by research mode and five Master's student by coursework mode. He was also an examiner (three Ph.D and one M.Sc). His current research focus is renewable energy, particularly solar energy technology, micropower systems, solar drying systems and advanced solar thermal systems (solar-assisted drying, solar heat pumps, PVT systems). He has published more than 120 peer-reviewed papers, of which 25 papers are in the ISI index (20 Q1, impact factor more than 4) and more than 70 papers are in the Scopus index. He has 16 currently accepted manuscripts, 20 manuscripts currently under review and two book chapters. In addition, he has published more than 70 papers in international conferences. He has a total citations of 830 and a h-index of 14 in Scopus (Author ID: 57195432490). He has a total citations of 1416 and a h-index of 20 in Google Scholar. He has been appointed as reviewer of high-impact (Q1) journals, such as Renewable and Sustainable Energy Reviews, Energy Conversion and Management, Applied Energy, Energy and Buildings, Applied Thermal Engineering, Energy, Industrial Crops and Products and so on. He has been appointed as reviewer of reputatable journals, such as Drying Technology, International Journal of Green Energy, Biosystem Engineering, Journal of Sustainability Science and Management, Journal of Energy Efficiency, Sains Malaysiana, Jurnal Teknologi and so on. He has also been appointed as editor of journals. He has received several awards, such as the Gold Medal Award at the International Ibn AlHaytham's Al-Manazir Innovation and Invention Exhibition 2011, the Silver Medal Award at the International Technology EXPO (ITEX) 2012, the Silver Medal Award at the Malaysia Technology Expo (MTE) 2013, the Bronze Medal Award at International Exposition of Research and Invention (PECIPTA) 2011 and two Bronze Medal Awards at PECIPTA 2017. He has also been invited as speaker in the Workshop of Scientific Journal Writing; Writing Scientific Papers Steps Towards Successful Publish in High Impact (Q1) Journals. He owns one patent and two copyrights.



Prof. Dr. Mohd Hafidz Ruslan currently is the Deputy Director and Head of Postgrade Studies of the Solar Energy Research Institute (SERI) UKM, Malaysia. His current research focuses on solar energy, especially solar thermal technology, heat pump system, solar water heating and solar drying systems. He has published more than 150 peer-reviewed papers in ISI and Scopus index. Addition, he has published more than 100 papers in international conferences. His total citations of 1541 by 1077 documents and h-index of 22 in Scopus index (Author ID: 6504666472). His total citations of 2564 and h-index of 27 in google scholar index. His research interest mainly in solar thermal technology (solar PV/T system, solar drying, heat pump system and soalr water heating system).

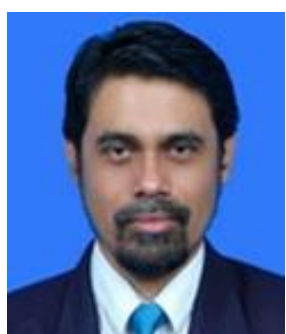

Prof Dato' Dr. Kamaruzzaman Sopian graduated with the BS Mechanical Engineering from the University of Wisconsin-Madison in 1985, the MS in Energy Resources University of Pittsburgh in 1989 and $\mathrm{PhD}$ in Mechanical Engineering from the Dorgan Solar Laboratory, University of Miami at Coral Gables in 1997. He has been involved in the field of renewable energy for more than 25-years. He has secure research funding from the Malaysian Minstry of Science and Malaysian Ministry of Education and industry for more than USD 6 million. He has conducted renewable enery courses the Asian School of Energy (2007-2014) funded by ISESCO, COMSAT, TIKA and UNESCO. He has published over 800 research papers in journals and conferences (SCOPUS h index $=49$, no. of citation=8181) (Google Scholar $\mathrm{h}$ index $=60$, no. of citation=13761). A total of $32 \mathrm{MSc}$ (coursework), $15 \mathrm{MSc}$ (research mode) and $40 \mathrm{PhD}$ supervised and completed. 